\title{
Diversity of Quinoa in a Biogeographical Island: a Review of Constraints and Potential from Arid to Temperate Regions of Chile
}

\author{
Didier BAZILE ${ }^{1}$, Enrique A. MARTÍNEZ ${ }^{2}$, Francisco FUENTES ${ }^{3 *}$ \\ ${ }^{I}$ CIRAD, UPR GREEN, TA C-47/F, Campus International de Baillarguet, F-34398 Montpellier, France; didier.bazile@cirad.fr \\ ${ }^{2}$ Centro de Estudios Avanzados en Zonas Aridas CEAZA, Av. Raúl Bitrán s/n, Casilla 554, La Serena, Chile; Facultad de Ciencias del Mar, Universidad \\ Católica del Norte,Larrondo 1281, Coquimbo,Chile; enrique.a.martinez@ceaza.cl \\ ${ }^{3}$ Rutgers, The State University of New Jersey, Department of Pharmaceutics, Ernest Mario School of Pharmacy, 160 Frelinghuysen Road, Room 013, \\ Piscataway, NJ08854, United Sates of America; francisco.fuentes.carmona@rutgers.edu (*0rresponding author)
}

\begin{abstract}
Chile, isolated by a hyper-arid desert in the north, the Andes Range to the east and the Pacific and Antarctic waters (west and south), has a highly endemic flora. This hotspot of biodiversity is in danger not only due to increasing desertification, but also because human activities can diminish agrobiodiversity. Quinoa (Chenopodium quinoa Willd.) is an Andean species producing highly nutritious grains, which almost disappeared from Chile during the Spanish colonization. Today less than 300 small-scale and highly isolated farmers still grow it as a rain-fed crop. This review describes the biogeographical-social context of quinoa in Chile, and its high genetic diversity as a product of a long domestication process, resulting in numerous local landraces whose conservation and use for breeding improved varieties is of paramount importance. We suggest the term "lighthouse crop" to emphasize its contribution to small scale ecological and bio diverse agriculture, particularly in stressful environments, to promote a healthier nutrition and more equitable markets in the world. Furthermore this crop and its exceptional nutritional properties were invoked by the United Nations Food and Agriculture Organization (FAO) to promote its use worldwide, and to declare 2013 the International Year of Quinoa.
\end{abstract}

Keywords: agrobiodiversity, agroecosystems, Chenopodium quinoa, conservation, cropping systems, lighthouse crop

\section{Introduction}

Agriculture is crucial not only in the context of globalization (Harvey, 2005), rural development and food production (FAO, 1996), but also because it hosts different models of social organization and cultural identity (FAO, 2011). In consideration of all these factors, the year 2013 was declared "The International Year of Quinoa" by the United Nations Food and Agriculture Organization (FAO), "in recognition of the indigenous peoples of the Andes who have traditionally protected and preserved quinoa as a food for present and future generations thanks to their longstanding knowledge and cultivation practices which are in harmony with nature" (Bazile et al., 2014; Ruiz et al., 2014). For these reasons quinoa could be considered a lighthouse crop for world family agriculture. The term lighthouse crop was suggested by Brush (2002), precisely for pointing out the value, and largely ignored farmers' costs, of conserving crop genetic resources, particularly if these are endangered while being also highly biodiverse, which is the case of quinoa in Chile (Fuentes et al., 2012).

Quinoa (Chenopodium quinoa Willd.) is an Andean cereal-like crop resistant to drought, poor soils and high salinity that can be grown from sea level to an altitude of
4,000 meters, and can withstand temperatures between -8 (Jacobsen et al., 2007) and $38^{\circ} \mathrm{C}$ (Zurita-Silva et al., 2014). Because it belongs to the Amaranthaceae or subfamily Chenopodioideae, it is more closely related to sugar beet and spinach than to the cereals (Gandarillas, 1979). More importantly, it yields grains with highly nutritional and functional properties, as it has all the amino acids, including all the essentials, trace elements, and many vitamins recommended in the human diet (Vega-Galvez et al., 2010; Fuentes and Paredes-Gónzalez, 2014).

Worldwide demand for this crop has been increasing (The Economist, 2012). Bolivia and Peru produce the vast majority of the commercial quinoa, while the FAO challenges aim also to promote interest for quinoa, both in terms of consumption for a healthier wellbeing and for production to fight poverty. Chile, in contrast with its neighbours from Peru and Bolivia has lost the social memory of this crop, as already noted in the last century (Looser, 1943) when the plant was even considered locally extinct in the southern part of the country (Simmonds, 1965). Today, the loss of social memory with respect to ancient crops like quinoa is also due to farmers being isolated from one another (Bazile et al., 2012). 
Chile is biogeographically isolated from neighbouring countries in the South American cone due to three main natural barriers: the extremely arid Atacama Desert in the north, the high Andes Range on the east and the Pacific Ocean to the west and south, the latter influenced by cold Antarctic waters (Fig. 1). This isolation plus the encounter of two types of floras (Subtropical and Mediterranean) contribute to form in arid Chilean lands hotspots of high biodiversity (Squeo et al., 2001). Today, less than 300 small-scale farmers (Tab. 1) preserves some 400 landraces of quinoa using different agricultural practices (Alfonso-Bécares, 2008; Alfonso-Bécares and Bazile, 2009; Bazile et al., 2014). These farmers are isolated from one another as they are distributed in three main regions (Fig. 1) in the northern Altiplano at 4,000 m elevation, land of the ancient Aymara culture, located in the Tarapacá region $\left(19^{\circ} \mathrm{S}\right)$ where no other agro-industrial crops can grow, 2 ) in the poor and arid soils along the coast in the O'Higgins Region $\left(34^{\circ} \mathrm{S}\right)$, and, 3 ) in the south coldtemperate Araucanía Region $\left(39^{\circ} \mathrm{S}\right)$ where quinoa is grown as a rain-fed crop mainly by women. Men, in the rainier southern Chile, rather concentrate to cultivate wheat and performing animal rearing, or are employed by the agro-forestry industries (Martínez et al., 2010). Isolation and cultural differences have helped to preserve quinoa cultivation in these regions with an unexpectedly high genetic diversity (Anabalón-Rodríguez and Thomet-Isla, 2009; Fuentes et al., 2009a, b, c). Quinoa has been collected at even more southern latitudes, reaching to $47^{\circ} \mathrm{S}$ like the study of Matiacevich et al. (2006), and Ceccato et al. (2011), both reporting seed sources from Chadmo in Chiloe Island $\left(\right.$ at $42^{\circ} \mathrm{S}$ ) or the collections reported by Wilson (1990), Wilson and Manhart (1993), and Jara-Valdivia and Hocdé (2009), but recent efforts of the authors to find quinoa farmers at Chiloe Island $\left(41^{\circ}-43^{\circ} \mathrm{S}\right)$ have not yet been successful.

The aim of this review is to describe the importance of biogeographical and social features affecting small-scale farmers, particularly those from arid zones, through the case study of quinoa in Chile and its genetic diversity. Finally, an

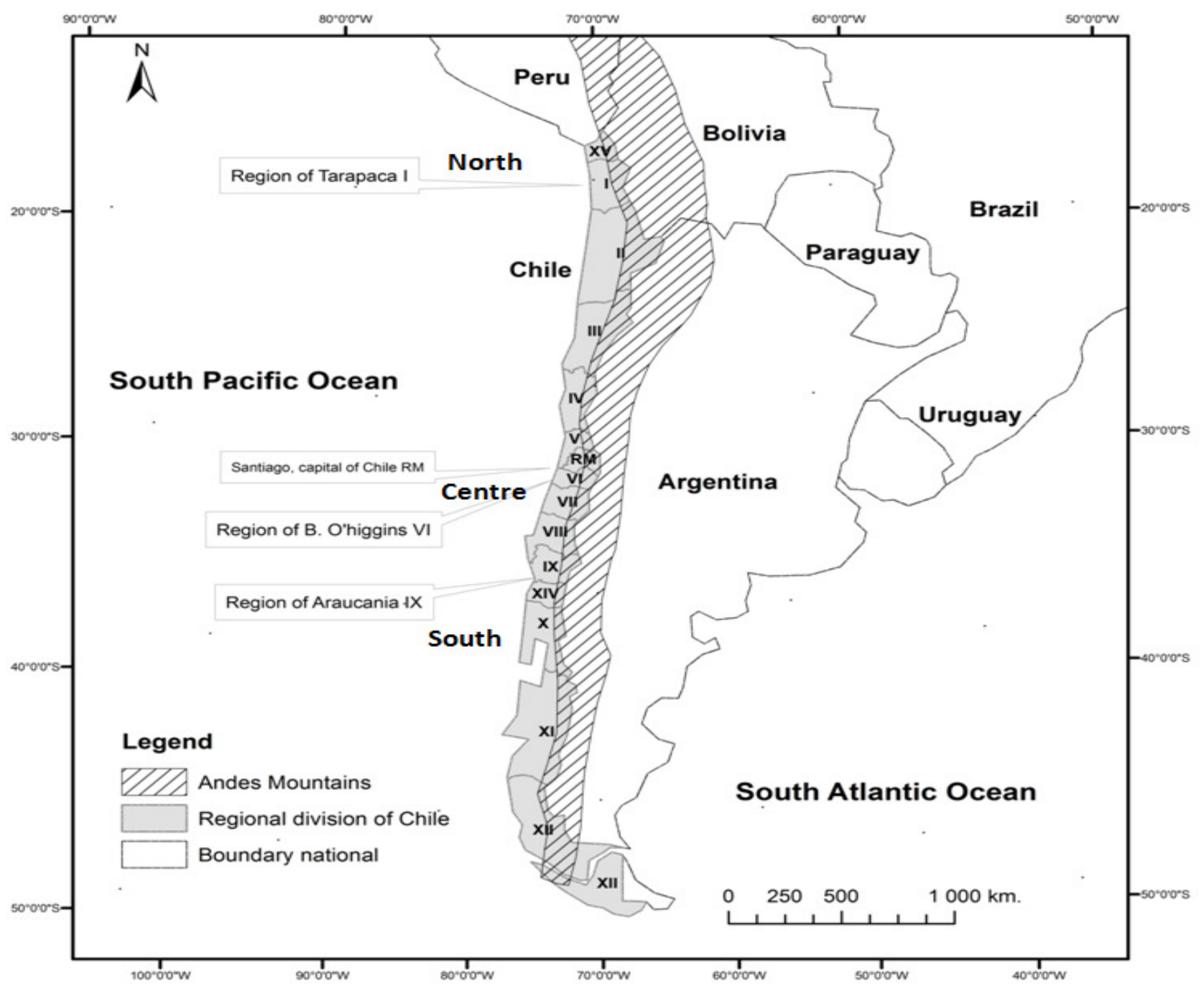

Fig. 1. Macrozones of quinoa cultivation in Chile with associated localities and its political isolation with respect to other South American countries. The Andes Range constitutes the great eastern barrier 
291

Tab. 1. Climate and diversity of farming systems/agricultural practices of quinoa in the three ancestral production zones of Chile

\begin{tabular}{|c|c|c|c|c|}
\hline & Variable & North & Centre & South \\
\hline $\mathrm{i}$ & Area & Tarapaca and Antofagasta Regions & O’Higgins and Maule Regions & Araucania Region \\
\hline ii & Altitude (m.a.s.l) & $3,500-4,000$ & $0-500$ & $0-1,500$ \\
\hline iii & Rainfall (mm/year) & $100-200$ & $500-800 \#$ & $1,000-2,000$ \\
\hline \multirow[t]{4}{*}{ iv } & Temperatures $\left({ }^{\circ} \mathrm{C}\right)$ & & & \\
\hline & Average high & 11.5 & 21.5 & 17.0 \\
\hline & Daily mean & 4.5 & 14.5 & $8.5-12.5^{\wedge}$ \\
\hline & Average low & $<0.0$ & 7.5 & $6.0+$ \\
\hline $\mathrm{v}$ & Soil types & Alkaline, volcanic/sandy loam & Neutral, clay & Acid, loam \\
\hline vi & Ethnicity & Aymara and Quechua & - & Mapuche \\
\hline vii & Number of producers & $>170$ & $>70^{*}$ & $>50^{*}$ \\
\hline viii & Hectares & 1,374 & $130^{*}$ & $10^{*}$ \\
\hline ix & Production (tonnes) & 802 & $100^{*}$ & 2,9 \\
\hline $\mathrm{x}$ & Grain yield $(\mathrm{kg} / \mathrm{ha})$ & 580 & 978 & 1,074 \\
\hline xi & $\begin{array}{l}\text { Gross production values per farm } \\
\text { (GPV) }\end{array}$ & $\begin{array}{c}\text { US\$36,854 (Tarapaca), US\$ } \$ 5,330 \\
\text { (Antofagasta) }\end{array}$ & US\$25,970-26,770 & US\$262,436 \\
\hline xii & $\begin{array}{l}\text { Mean number of landraces per } \\
\text { field crop }\end{array}$ & 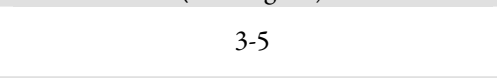 & 1 & $1-3$ \\
\hline xiii & Seed types & $\begin{array}{c}\text { Seed colors: red (lirio in Aymara), pink } \\
\text { (canche), white (janku), yellow (churi), brown } \\
\text { (chullpe), dark red (pandela) and orange } \\
\text { (pera) }\end{array}$ & White or yellow & $\begin{array}{l}\text { Brown seeds associated } \\
\text { with red panicles, and } \\
\text { yellow seeds associated } \\
\text { either with yellow or red } \\
\text { panicles }\end{array}$ \\
\hline xiv & Sowing period & August to October & October to November & October \\
\hline $\mathrm{xv}$ & Harvest period & $\begin{array}{c}\text { April - May (Tarapaca Region), January- } \\
\text { February (Antofagasta Region) }\end{array}$ & February to April & March \\
\hline xvi & Other crops & Potatos & $\begin{array}{l}\text { Conifer plantations, wheat, } \\
\text { corn, barley, oat and potatoes }\end{array}$ & Beans, potatoes, and corn \\
\hline
\end{tabular}

vii, viii, ix and x: information from 2007 National Agricultural Census (INE 2007) completed and corrected by field works.

\# Between the growing quinoa season (October to April) rainfall may reach as low as $40 \mathrm{~mm}$.

$\wedge$ Lowest mean temperatures at Andean foothills and higher at coastal zones.

+ With coldest mornings below zero and at averaging $1.0^{\circ} \mathrm{C}$.

${ }^{*}$ Minimum estimation

attempt will be made to draw lessons for the future from all this information, especially on how to optimize the potential of forgotten crops, particularly in lands suffering from strong water deficit.

\section{Quinoa as an important lighthouse crop for family farming}

Quinoa, a food plant of the Andes, has been cultivated for at least 5,000 years (Fuentes et al., 2012). It produces grains of high nutritional value, thanks mainly to the quality and quantity of its proteins, supplying all the essential amino acids (Galwey, 1992; Schlick and Bubenheim, 1996; VegaGalvez et al., 2010). This high protein value is particularly relevant in arid zones, since the production of meat-derived proteins has an extremely high water footprint (Chapagain and Hoekstra, 2008); this is not the case for quinoa, a droughttolerant plant. Quinoa grains also contain significant amounts of vitamins $\mathrm{C}, \mathrm{E}$ (tocopherols) and $\mathrm{B}$ (B1, $\mathrm{B} 2, \mathrm{~B} 3)$ along with important minerals $(\mathrm{Ca}, \mathrm{K}, \mathrm{Fe}$, $\mathrm{Mg}, \mathrm{Mn}, \mathrm{P}$ ), and isoflavones that might help in breast milk production (Lutz et al., 2013); quinoa has no gluten, and its fatty acids are high quality lipids. Such a combination of factors contributes to the excellent antioxidant properties of this plant (Fuentes and Paredes-Gónzalez, 2014). Even the seed coat saponins, previously considered as anti-nutrients due to their bitter taste, can now be extracted for industrial and biomedical purposes (Jancurová et al., 2009). All these features have been confirmed for Chilean quinoas (Miranda et al., 2012 a, b; 2013).

Associated with its broad geographical distribution in Chile, quinoa displays high genetic diversity (Fuentes et al., 2008; 2009b), still preserved today by local farmers (Fuentes et al., 2012). Several recent studies have shown that the ability of quinoa to survive in isolated and extreme sites in a vast territory, from the borders of the Bolivian Altiplano to the coast and along a north-south gradient extending for over $3,000 \mathrm{~km}$, mostly under organic management, is reflected in physiological features associated with very efficient stress tolerance mechanisms (Bazile and Negrete, 2009; Fuentes and Bhargava, 2011; Orsini et al., 2011; Ruiz-Carrasco et al., 2011).

This is why we propose the definition of quinoa as a lighthouse crop, in accord with FAO's decision to dedicate the year 2013 to this grain plant (Bazile, 2014). Quinoa can, in fact, contribute to promote all the above-mentioned values, and could represent a source of food and income guiding (as a lighthouse) many farmers involved in small-scale family agriculture (the FAO focus for 2014) (Bazile et al., 2014). 
Re-constructing the history of quinoa's southward expansion from the central Andes to Chile

Quinoa, being an allotetraploid plant, has as the putative ancestor either Chenopodium berlandieri, distributed in North America, or the Andean species Chenopodium hircinum (Wilson and Heiser, 1979; Heiser and Nelson, 1974; Fuentes et al., 2009a). More recent studies even suggest Old World relatives (Kolano et al., 2011). Its center of origin and first domestication is thought to have occurred around Lake Titicaca in the Peruvian-Bolivian highlands (where its highest recorded diversity is found), from where it dispersed northward and southward over the last 5,000 years (Kadereit et al., 2003, Fuentes et al., 2012). Today quinoa cultivation in South America ranges from a latitude of $2^{\circ} \mathrm{N}$ in Colombia to $47^{\circ} \mathrm{S}$ in Chile, and from sea level to $4,000 \mathrm{~m}$ elevation in the Altiplano region (Fuentes et al., 2009c; Zurita-Silva et al., 2014).

The dry desert of today's northern Chile, which was wetter in the past, must have allowed its southward expansion by seed exchanges among ancient peoples who, therefore, adapted the crop to local conditions. These landraces were initially adapted to the short-day photoperiods of the highlands. Later cultivation expanded to other soils, climatic conditions and photoperiods typical of more southern latitudes (longer spring and summer days/shorter nights), and to lower and coastal areas, reaching the south of Chile (Bazile et al., 2014). Today seed size reflects this adaptation process, tending to be smaller at southern latitudes, but still of high nutritional value (Miranda et al., 2012a, b; 2013). Seed colour varies greatly from black, which is dominant over red and yellow, to white, which is recessive to all colours (Fig. 2) (Bhargava et al., 2005).

Quinoa probably arrived in Chile by transmission of seeds even before the Inca's influence on
Chilean aboriginal groups, at least 3,000 years ago (Planella $e t$ al., 2011). These ancestral peoples lived in distinct agro- and ecological contexts, from the highlands (Altiplano) in the north $\left(17^{\circ} \mathrm{S}\right)$ to Chiloe Island $\left(42^{\circ} \mathrm{S}\right)$, and even further $\left(47^{\circ} \mathrm{S}\right.$, Puerto Rio Tranquilo) in the south. However, during the Spanish conquest cultivation of this crop was strongly discouraged because of its importance for the local people, and because it was considered sacred in the indigenous culture (Ruas et al., 1999). However, the difficulties of processing quinoa (dehusking to remove saponins) may have also discouraged ancestral growers as well as conquerors more prone to eat easier foodstuff like corn (Smith, 2006). Historical documents written by Pedro de Valdivia (Anonymous, 1861), conqueror of Chile in 1535, sent to King Carlos V of Spain, reveal the presence of quinoa in Chile from north to south, both in valleys and mountains. In the 19th century quinoa was described by the French naturalist Claude Gay during his expeditions to Chile; the chronicles written by Juan Ignacio Molina (Molina, 1810) provided details on local systems of production, making special reference to a southern variety called Dahue (quinoa in the Mapuche language), with ash-coloured leaves and white or greyish seeds.

According to Looser (1943), cultivation of quinoa almost disappeared in Chile during the first part of the 20 th century. It survived thanks to women and indigenous small-scale growers who cultivated it in the central zone at the north-eastern frontier with Peru and Bolivia (Lanino, 1976), and near sea level in Concepción and in Mapuche reserves, where it was also called quinhua or kinwua (Junge, 1978). The expansion routes of quinoa were identified by Fuentes et al. (2012), with the support of molecular markers. The expansion pattern implies a microevolutionary process, but also different ecological and agricultural types of exploitation
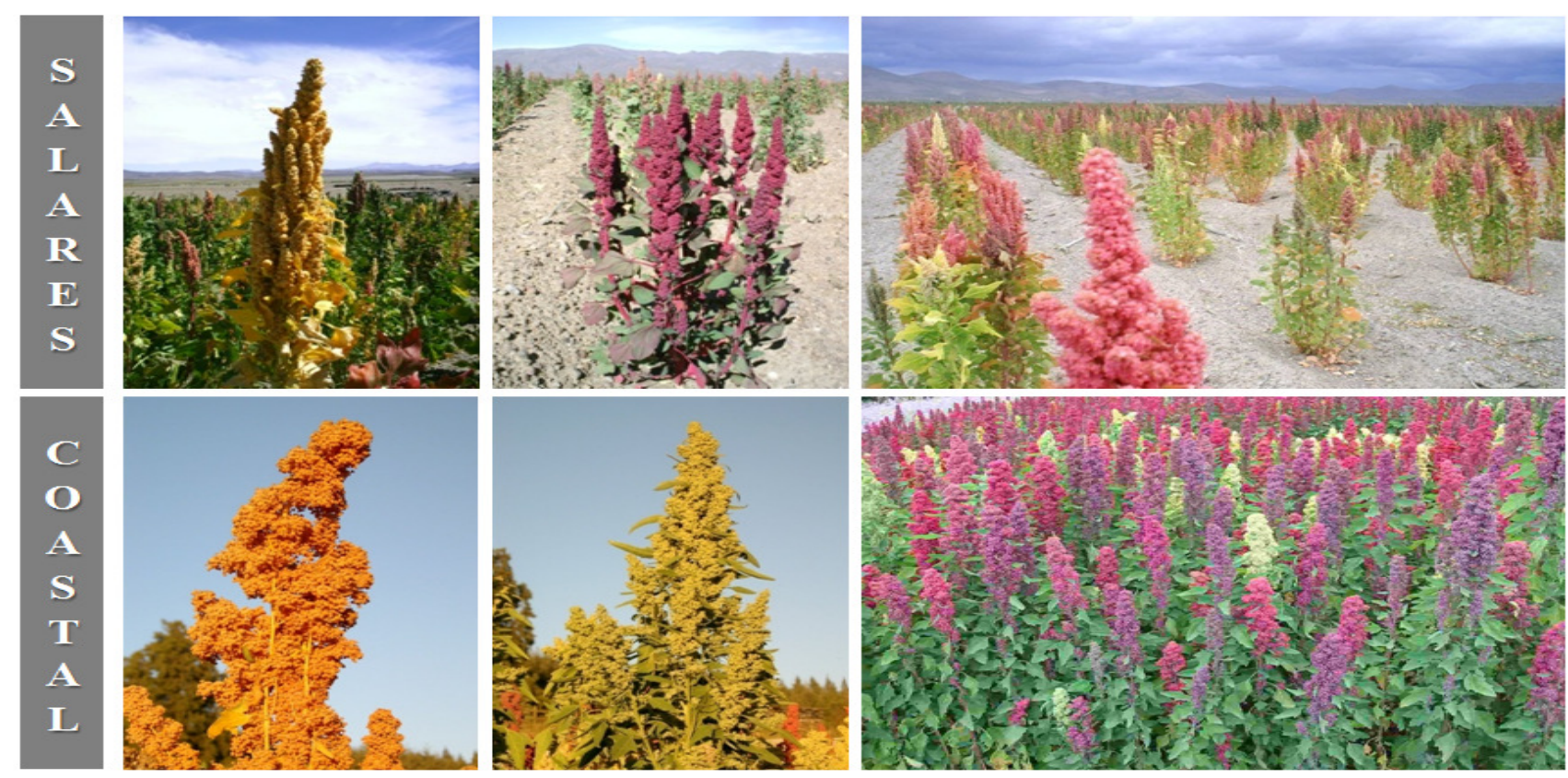

Fig. 2. Morphological variation of quinoa ecotypes cultivated in Chile. Salares (north) and Coastal (centre and south) ecotypes 
293

(Parra, 2007), that generated innovations and structural changes regarding recurrent human activities (Rescia et al., 2002).

The existence of particular adaptations to specific geographical areas along the Andes has led to the recognition of five ecotypes, each associated with diversity sub-centers: the Inter-Andean valleys ecotype (Colombia, Ecuador and Peru), the Highlands ecotype (Peru and Bolivia), the Yungas ecotype (Bolivian subtropical forest), the Salares (salt flats) ecotype (Bolivia, Chile and Argentina), and the Coastal (lowlands) or sea level ecotype (Chile) (Bazile et al., 2013). Cultivation of quinoa in Chile is based on the use of two ecotypes, the Salares and Coastal ecotypes (Fig. 2). The former is distributed in the Regions of Tarapaca and Antofagasta $\left(18-25^{\circ} \mathrm{S}\right)$ in northern Chile (Fig. 1) where precipitation fluctuates between 100 and $200 \mathrm{~mm}$ per year (Tab. 1), with precipitation occurring during the Southern Hemisphere summer from December to February. Here, highland indigenous communities traditionally cultivate their quinoa in saline soils using landraces closely related to those of the Salares ecotype of Bolivia, this being probably the only in-and-out gene flow across the today's political border.

In central Chile $\left(34^{\circ} \mathrm{S}\right.$, Fig. 1) and at more southern latitudes in the political Regions of O'Higgins $\left(35^{\circ} \mathrm{S}\right)$ to Los Lagos $\left(>40^{\circ} \mathrm{S}\right)$, several landraces belonging to the Coastal ecotype are cultivated at altitudes ranging between 0 and $500 \mathrm{~m}$ under rain-fed conditions. A major difference, compared to the extremely dry conditions, in which the Salares quinoa is grown in northern Chile, is that precipitation in central and southern Chile occurs during winter (500-1,900 mm per year; Tab. 1) (Bazile et al., 2014). The two ecotypes therefore display remarkable differences in terms of adaptation to altitude, drought and salinity, as well as to day length (Bertero, 2001; Zurita-Silva et al., 2014).

In Chile, quinoa is thus cultivated in three macro zones whose current climates, cultivated surfaces, and yields are summarized in Tab. 1.

These include:

-(i) the northern zone (Tarapacá and Antofagasta Regions), described as a "puna" (Di Castri, 1968) or altitude-steppe climate of marginal deserts (Köppen, 1931),

-(ii) the central zone (Libertador Bernardo O'Higgins and Maule Regions) with a more Mediterranean-type climate, and

-(iii) the southern zone (Araucanía Region) with a more rainy-temperate climate under the influence of cold Pacific currents (Fig. 1) (Di Castri, 1968).

The meteorological data indicate milder coastal conditions at Paredones (almost no temperatures below zero) compared to the highlands (Colchane) or to the southern (Temuco). Rainfall is very limited in the highlands and coastal zones during the crop cycle (October to April/May). Sowing before those dates will ensure rain falling. However frost risks, that could affect early seedling stages, also increase. Interestingly, Quinoa can also be found in other political regions of Chile such as Bio-Bio, Los Ríos, Los Lagos, and even as far south as Chiloe Island and Aysen Region at $47^{\circ} \mathrm{S}$ (Alfonso-Bécares, 2008; Alfonso-Bécares and Bazile, 2009).
Diversity of farming systems and agricultural practices: in situ conservation of farmers' landraces in three isolated regions

In addition to the high genetic diversity reported for Chilean quinoa (Fuentes et al., 2009b), recent studies have revealed differences in agricultural practices along the same north-south biogeographical gradient (Fuentes et al., 2012). However, the current emigration of local farmers from the Andean zones (Bazile et al., 2011), a form of cultural erosion, is threatening quinoa and may lead to a significant loss of those genetic combinations (genetic erosion) accumulated in locally adapted landraces through thousands of years of human-driven experimentation and selection (Fuentes et al., 2012). In Chile this kind of loosing of cultural knowledge for quinoa crop was stronger at the central zone between $29^{\circ} \mathrm{S}$ and $33^{\circ} \mathrm{S}$ (Vallenar to Santiago) where farming traditions were changed very early during the colonization process. Particularly due to the strong climatic similarities between the Mediterranean climatic origin of the crop plants the colonizers brought and the Chilean climate at those latitudes and times (16 ${ }^{\text {th }}$ century). Such climatic conditions have changed dramatically in the last century and affected the now drier ecosystems (Squeo et al., 2001) and also the associated agricultural practices (Jorquera, 2001), including the loosing of quinoa seeds (Martínez et al., 2009). Urbanization process and changes in jobs' trends in southern Chile (like growing of cultivated salmon industry in southern latitudes, beyond $40^{\circ} \mathrm{S}$ ) might have produced the same results but at more recent times (Jara-Valdivia and Hocdé, 2009).

Information obtained from interviews of quinoa farmers from the only three remaining isolated production zones, conducted by Alfonso-Bécares (2008), Aleman (2009), and Fuentes et al. (2012), are summarized in Tab. 1. Accordingly, the cultivation of quinoa in Chile is geographically diverse, and generates a wide range of agricultural practices. For example, farmers in the northern macro zone are organized in communities called "ayllus" in the local language. The traditional form of agriculture is characterized by the absence of chemical fertilization, and no chemical control of pests and diseases. The level of mechanization is low, and there is no formal selection of cultivars or breeding programs (Bazile et al., 2014). The soil recovers its fertility through field rotation and addition of llama manure. In relation with the field management of seed production, most of farmers (70\%) produce, consume and/or sell more than one type of quinoa (Fig. 2). This is a useful approach to face the environmental risks (e.g., drought, frost) of the Altiplano, since one landrace may be more tolerant than another (Adolf et al., 2012). On the other hand, we have identified that quinoa cultivation in this zone is endangered by the fact that the "tatas" (oldest community members) are well on in years (on average more than 60 years old). Only $25 \%$ of the young people still live in highland municipalities, and movement to the nearby coastal cities of Antofagasta, Iquique and Arica has increased due to new job opportunities given by metal extraction of mining activities. This migration leads to instability of labour availability on farms (daily agricultural workers), as well as having a considerable impact on the traditional structure of indigenous communities (Fuentes et al., 2012). 
Quinoa in the central zone is typically grown by a few isolated farmers which own an average of one hectare (Alfonso-Bécares, 2008). The average age of farmers in this area is also 65 years, and they cultivate mostly one type of quinoa, the white landrace (Fig. 2); which in $38 \%$ of cases, the seed is acquired through family heritage and in $46 \%$ from neighbouring farmers. Some farmers had good links with the Las Nieves Agricultural Cooperative, an important and historical farmers' regional organization; this Cooperative can market the totality of their quinoa production (Alfonso-Bécares, 2008). In the southern macro zone, the amount of land dedicated to quinoa, where it is called kinwa in the Mapudungun language, is very limited. Different studies have revealed that many women belonging to the indigenous Mapuche community grow quinoa in small family gardens (normally about $1,000 \mathrm{~m}^{2}$ ) next to their homes (Aleman, 2009; Alfonso-Bécares, 2008). These cultivated areas never appear in the Chilean National Agricultural Census (INE, 1997; 2007), which may explain why little is known about quinoa cultivation in the south. The most relevant difference between highland and southern quinoa is that the latter is produced in zones with more rainfall and at lower altitudes, thus generating the need for totally different management practices, particularly with respect to seeding density (higher in the south) and soil depth (deeper in the north, due to low soil fertility and moisture) (Fig. 2) (Bazile et al., 2014).

The commercial value of farmers' activity in the tree mentioned zones of Chile has been estimated. INDAP, a governmental institution created to aid small-scale farmers ( $<12 \mathrm{ha})$, and Qualitas A.C. (personal communication) have calculated the gross production values per farm (GPV), including the three farming areas of quinoa, which reached an annual average of US\$ 15,839 in 2007. It is interesting to note that the smallest farms (less than US\$ 8,250) are located in the northern region, at Colchane, where $67 \%$ of the country's quinoa producers are concentrated (Tab. 1). Thus, we have estimated that the annual cost of producing quinoa is around US $\$ 1,000$ per hectare what can be used to give a scope of benefits if we consider that in 2014 the price of quinoa on the European market has raised to 13 Euros per kilo, what stands for US $\$ 17,700$ per ton (consider that the price of wheat was only US $\$ 325$ per ton in April $2014^{1}$ ). The scope for growth in production and benefits is nowadays very high.

Relationship between the types of quinoa grown in different areas and genetic studies: a biodiversity treasure in farmers'hands

Genetic diversity studies of quinoa suggest that it may have passed through at least three bottleneck genetic events, which did not, however, lead to extreme genetic loss in the different diversity sub-centers (Jellen et al., 2011). The first and potentially most severe event may have occurred when two diploid ancestors of quinoa underwent a hybridization/chromosome doubling event. The second may have occurred when quinoa was domesticated from wild tetraploid ancestors, suggesting that quinoa could have been domesticated twice: once in the high Andes and a second time in the Chilean and Argentinean lowlands (Christensen et al., 2007; Fuentes et al., 2009a). The third, considered a political bottleneck, has lasted more than 400 years, from the Spanish conquest until the present time, a phase during which quinoa has been marginalized from production processes due to its important medicinal, social and religious roles for the indigenous population (Cusack, 1984). Nowadays, a fourth potential bottleneck event, caused by farmer migration from rural zones to urban centers resulting in abandoned villages and farms, is exposing quinoa to the risk of further genetic erosion (Fuentes et al., 2012). This is particularly true in Chile where germplasm diversity is conserved mostly in small-scale farms, and where the advance of agro-industry and exotic forestry for cellulose, both for export, is leading to land ownership becoming concentrated in fewer and fewer hands (Martínez et al., 2010).

The genetic distribution initially hypothesized by Wilson (1988a, b), based on electrophoretic and morphometric data, partially coincides with reports based on co-dominant molecular markers (SSR, Simple Sequence Repeats), suggesting that northern Chile's quinoa is in fact closely related to Bolivian varieties of the Salares ecotype (Christensen et al., 2007). Molecular data also provided evidence for the introduction of materials from the Andean highlands of Peru into the Antofagasta highland region of Chile (Fuentes et al., 2009a). The dominant morphology in most of the Chilean highland quinoas corresponds thus to the Salares ecotype, generally characterized by large seeds $(\sim 2 \mathrm{~mm})$, early maturation ( 150 days), a predominantly branching growth habit and amaranth-like panicles (Rojas, 2003; Fuentes et al., 2009b; Zurita-Silva et al., 2014) (Fig. 2).

Genetic diversity was thought to be higher in northern Chile, due to its proximity to the center of origin in Bolivia. However, recent molecular data of Coastal (lowland) quinoa accessions from central and southern Chile have shown these to be much more diverse than expected (Anabalón-Rodríguez and Thomet-Isla, 2009; Fuentes et al., 2009a, Miranda et al., 2012b). The higher genetic diversity (e.g., high proportion of single alleles) observed in this ecotype relative to that from northernmost Chile (highland ecotype) may be explained by a mixed selfing/outcrossing mating system commonly described by breeders, and by a constant intra- or inter-specific exchange of genetic information with the wild and ancestral relatives C. album and/or C. hircinum (Fuentes and Zurita-Silva, 2013). Seeds from archaeological sites recently confirmed natural signs of an active weed-quinoa complex in southern Chile (Fuentes et al., 2008; 2009a; Rana et al., 2010). Interestingly, molecular data analyses have revealed a bifurcated pattern of diversity within the southernmost quinoa germplasm, which has been described as representative of two coastal areas. Finally, quinoa from the central macro zone might have also passed through a local bottleneck, as supported by population molecular data showing lower heterozygosity values and a lower proportion of polymorphic loci than in southern accessions (Fuentes $e t$ al., 2012; Miranda et al., 2012b). 
295

In our previous studies, quinoa seeds from Chilean breeding programmes have revealed reduced genetic diversity, evaluated through molecular markers developed by Mason et al. (2005), when compared to farmers' landraces, showing that selection processes at the intra-farm level are not common (Bazile et al., 2014; Martínez et al., 2008). Thus, the genetic diversity decreases, as expected, after mass selection carried out by breeders. A different result could be observed for hybrid cultivars as the one created by cross fertilization between a Chilean and an Equatorian one (Von Baer et al., 2009). This cultivar actually has a genetic diversity background in between those from the High Andes and those from the centre and southern Chile (Fuentes et al., 2009b; 2012). This hybrid state can also be observed through its nutritional intermediate features (Miranda et al. 2012a, b).

Conserving quinoa biodiversity is also a means of conserving nutritional quality, since different landraces may vary in the content of nutrients (e.g., proteins, trace elements) and health-promoting compounds (Miranda et al., 2011; 2012a, b; Fuentes and Paredes-Gónzalez, 2014). Moreover, the many landraces still existing today offer the potential to find, or breed, suitable genotypes adapted to different and even extreme agro-ecological conditions. Indeed, one of FAO's motivations for dedicating 2013 to quinoa is that it "offers poor communities, living in harsh environments, options to improve their livelihoods, generate income, achieve food security, and enjoy better nutrition and health". For example, the Salares ecotype from the Chilean highlands can be grown for grain and forage in lowland areas of the Atacama Desert (precipitation $<100 \mathrm{~mm}$ /year), where high temperatures and low relative humidity converge during the cropping season (Fuentes and Bhargava, 2011). On the other hand, studies with Coastal (lowland) quinoas, typically from cold-temperate environments in the south $\left(35^{\circ} \mathrm{S}\right)$, suggest that reintroduction of these landraces in arid zones is feasible, even under prevailing conditions of low rainfall and poor soils, with a minimum of irrigation (Martínez et al., 2009; Bazile et al., 2014).

\section{Concluding remarks}

Despite the limited extent of quinoa production in Chile, agro-ecosystem diversity is extremely high, and partially protected by biogeographic isolation. These systems are, however, exposed to risks from desertification and from social constraints due to the extreme exportationfocused agricultural model often rendering land property into fewer and fewer owners, and on top of that an eroded rural demography where replacement of old generations is not occurring. Local extinctions of quinoa have already occurred in many places of Chile, more than in the neighbouring countries. In this context, Chilean agroecosystems are facing greater challenges due to the intensive farming that may lead to one (or few) genotypes destined for local and international markets. This extinction risk threatens all minor crops and particularly quinoa, a highly nutritious and stress tolerant crop, which is cultivated in Chile by less than 300 smallholder farmers. These farmers, mostly using a form of agriculture in harmony with nature, have in their hands the genetic diversity of quinoa, hundreds of landraces belonging to two ecotypes (Salares and Coastal) out of the five ecotypes of the Andean region. These landraces are distributed through a broad environmental spectrum (in terms of photoperiod and pedo-climatic conditions) from the north $\left(18^{\circ} \mathrm{S}\right)$ to the south $\left(42^{\circ} \mathrm{S}\right)$ of Chile so that not all of them grow in all places. The high genetic diversity of quinoa is tightly linked to the cultural diversity of the people who have been cultivating and adapting quinoa to salinity and other forms of stress over the last 3,000 years. Then, preserving quinoa's genetic diversity, very well adapted to highly different soils and climates, also means preserving cultural diversity, including farming diversity. Quinoa's extraordinary nutritional value and diversity also offer huge potential for ecological family farming and participatory breeding programs (private or public) as an important resource to fight poverty and hunger in arid and saline areas throughout the world. In this sense, quinoa could be considered a lighthouse crop. Conventional farming would be also another possibility for this crop, but only agroecological practices are able to valorize quinoa's biodiversity in cropping systems and to provide a healthy product to consumers. The high variety of Chilean landraces, adapted to different latitudes, makes this crop potentially cultivable almost anywhere in the world, including Europe, Asia and Africa (Bazile and Baudron, 2014). However, scientists still face many challenges to save quinoa from genetic erosion in Chile and elsewhere in the Andean region. This task needs new market opportunities and equity as well as sharing of scientific knowledge with a broader public and with institutions that can contribute to this conservation mission.

\section{Acknowledgements}

The authors wish to express their appreciation to farmers for telling us their stories and practices, and also to projects that funded most of the reported research activities: BRG08, ICGEB-TWAS (CRP.PB/CHI06-01), IMAS (ANR07 BDIV 016-01), FONDECYT (1060281 and 1100638), IRSES (PIRSES-GA-2008-230862) and Innova Chile of CORFO (04CR9PAD04).

\section{References}

Adolf VI, Shabala S, Andersen MN, Razzaghi F, Jacobsen SE (2012). Varietal differences of quinoa's tolerance to saline conditions. Plant Soil 357:117-129.

Aleman J (2009). Caractérisation de la diversité des variétés et des modes de culture du Quinoa dans les communautés Mapuche du Sud du Chili. Thesis of Agronomy, Univ. Montpellier Sup'Agro, France.

Alfonso-Bécares D (2008). La gestion de la biodiversité par les paysans: Le quinoa au Chili. Thesis Master 2, Spécialité Recherche: Innovations et Développement des Territoires Ruraux. SupAgro-IAMM-UMIII-CIRAD, MontpellierFrance.

Alfonso-Bécares D, Bazile D (2009). La quinoa como parte de los sistemas agrícolas en Chile: 3 regiones y 3 sistemas. Revista geográfica de Valparaíso 42:61-72. 
Anabalón-Rodríguez L, Thomet-Isla M (2009). Comparative analysis of genetic and morphologic diversity among quinoa accessions (Chenopodium quinoa Willd.) of the South of Chile and highland accessions. J Plant Breed Crop Sci 1:210-216.

Anonymous (1861). Cartas de don Pedro de Valdivia al emperador Carlos V. Colección historiadores de Chile. Tomo I. Imprenta del Ferrocarril. Santiago de Chile.

Bazile D, Negrete J (2009). Quínoa y biodiversidad: ¿cuáles son los desafíos regionales? Revista Geográfica de Valparaíso 42:1141.

Bazile D, Carrié C, Vidal A, Negrete J (2011). Modélisation des dynamiques spatiales liées à la culture du quinoa dans le Nord chilien. Mappemonde (102) (article 11204): 14 p http://mappemonde.mgm.fr/num30/articles/art11204.html.

Bazile D, Martínez EA, Hocdé H, Chía E (2012). Primer Encuentro Nacional de Productores de Quínoa de Chile: Una experiencia participativa del proyecto internacional IMAS a través de una prospectiva por escenarios usando una metodología de "juego de roles". Tierra Adentro (INIA) 97:48-54.

Bazile D, Baudron F (2013). Dinámica de expansión mundial del cultivo de la quinua respecto a su alta biodiversidad. In: Bazile D, Bertero HD, Nieto C (eds.). Estado del arte de la quinua en el mundo en 2013. Santiago: FAO - CIRAD 49-64 http://www.fao.org/3/a-i4042s/index.html.

Bazile D, Fuentes F, Mujica A (2013). Historical perspectives and domestication, p. 16-35. In: Bhargava Atul, Srivastava Shilpi. Quinoa: botany, production and uses. Wallingford: CABI.

Bazile D (2014). Contesting Blossoming Treasures of Biodiversity article 42: 'Quinoa - is the United Nation's featured crop of 2013 bad for biodiversity?' - Quinoa, a model crop to examine the dynamics of biodiversity within agricultural systems. Biodiversity 15:3-4.

Bazile D, Martínez EA, Fuentes F, Chia E, Namdar-Irani M, Olguín P, Saa C, Thomet M, Vidal A (2014). La quínoa en Chile, p. 477-503. In: Bazile D. Bertero HD, Nieto C (eds.) Estado del arte de la quinua en el mundo en 2013. Santiago: FAO - CIRAD. http://www.fao.org/3/a-i4042s/index.htm

Bertero HD (2001). Effects of photoperiod, temperature and radiation on the rate of leaf appearance in quinoa (Chenopodium quinoa Willd.) under field conditions. Ann Bot 87:495-502.

Bhargava A, Rana TS, Shukla S, Ohri D (2005). Seed protein electrophoresis of some cultivated and wild species of Chenopodium (Chenopodiaceae). Biol Plant 49:505-511.

Brush SB (2002). The lighthouse and the potato: Internalizing the value of crop genetic diversity. Working Paper No 37, Political Economy Research Institute. University of Massachusetts, Amherst.

Castri Di F (1968). Esquisse écologique du Chili. In: DelmareDeboutteville C, Rapaport E (eds.) Biologie de l'Amérique Australe. Volume IV. Etudes sur la faune du sol. Documents biogéographiques. Extrait. Paris: Ed Centre National de la
Recherche Scientifique 7-52.

Ceccato DV, Bertero HD, Batlla D (2011). Environmental control of dormancy in quinoa (Chenopodium quinoa) seeds: two potential genetic resources for pre-harvest sprouting tolerance. Seed Sci Res 21:133-141.

Chapagain AK, Hoekstra AY (2008). The global component of freshwater demand and supply: An assessment of virtual water flows between nations as a result of trade in agricultural and industrial products. Water Int 33:19-32.

Christensen SA, Pratt DB, Pratt C, Nelson PT, Stevens MR, Jellen EN, Coleman CE, Fairbanks DJ, Bonifacio A, Maughan PJ (2007). Assessment of genetic diversity in the USDA and CIP-FAO international nursery collections of quinoa (Chenopodium quinoa Willd.) using microsatellite markers. Plant Genet Resour 5:82-95.

Cusack DF (1984). Quinoa: grain of the Incas. Ecologist 14:2131.

Food and Agriculture Organisation (FAO) (1996). Plan d'action mondial pour la conservation et l'utilisation durable des ressources phytogénétiques pour l'alimentation et l'agriculture. Rome, Italy.

Food and Agriculture Organisation (FAO) (2011). The state of food and agriculture. 147 p. Food and Agriculture Organization of the United Nations, Rome, Italy.

Fuentes F, Carevic AF, Jellen EN, Maughan PJ (2008). Evidencias arqueológicas de agricultura en el Desierto de Chile. In: Anales del $59^{\circ}$ Congreso Agronómico de Chile. La Serena, Chile.

Fuentes F, Espinoza PA, Von Baer I, Jellen EN, Maughan PJ (2009a). Determinación de relaciones genéticas entre Chenopodium quinoa Willd. del sur de Chile y parientes silvestres del género Chenopodium. Anales del XVII Congreso Nacional de Biología del Perú, 45. Tacna, Perú.

Fuentes F, Martínez EA, Hinrichsen PV, Jellen EN, Maughan PJ (2009b). Assessment of genetic diversity patterns in Chilean quinoa (Chenopodium quinoa Willd.) germplasm using multiplex fluorescent microsatellite markers. Conservation Genetics 10:369-377.

Fuentes F, Maughan PJ, Jellen EN (2009c). Diversidad genética y recursos genéticos para el mejoramiento de la quínoa (Chenopodium quinoa Willd.). Revista Geográfica de Valparaíso 42:20-33.

Fuentes F, Bhargava A (2011). Morphological analysis of quinoa germplasm grown under lowland desert conditions. J Agron Crop Sci 7:124-827.

Fuentes F, Bazile D, Bhargava A, Martínez EA (2012). Implications of farmers' seed exchanges for on-farm conservation of quinoa, as revealed by its genetic diversity in Chile. J Agr Sci 150:702-716.

Fuentes F, Zurita-Silva A (2013). Molecular studies, p. 168-184. In: Quinoa: Botany, Production \& Uses. Bhargava A, Srivastava S (eds.). CABI Publisher, Wallingford, UK.

Fuentes F, Paredes-Gónzalez X (2014). Perspectivas nutracéuticas de la Quínoa: Propiedades biológicas y aplicaciones funcionales, $\mathrm{p}$. 
297

341-357. In: Bazile D, Bertero HD, Nieto C (eds.). Estado del arte de la quinua en el mundo en 2013. Santiago: FAO-CIRAD http://www.fao.org/3/a-i4042s/index.html.

Galwey NW (1992). The potential of quinoa as a multi-purpose crop for agricultural diversification: a review. Ind Crop Prod 1:101-106.

Gandarillas H (1979). Mejoramiento genético. In: Tapia ME et al. (Eds.). Quinua y Kanihua, Cultivos Andinos. IICA, Bogotá, Colombia 65-82.

Harvey D (2005). A Brief History of Neoliberlism. Oxford's University Press, Oxford and New York, USA.

Heiser CB, Nelson CD (1974). On the origin of cultivated Chenopods (Chenopodium). Genetics 78:503-505.

INE (1997). VI Censo Nacional Agropecuario. Available at (consulted on June 24, 2014):

http://www.ine.cl/canales/base_datos/otras_bases_datos.php.

INE (2007). VII Censo Nacional Agropecuario y Forestal. Available at (consulted on June 24, 2014):

http://www.ine.cl/canales/base_datos/otras_bases_datos.php.

Jacobsen SE, Monteros C, Corcuera LJ, Bravo LA, Christiansen JL, Mujica A (2007). Frost resistance mechanisms in quinoa (Chenopodium quinoa Willd.). Eur J Agron 26:471-475.

Jara-Valdivia P, Hocdé H (2009). Viajes de la quínoa en Chile. Revista Geográfica de Valparaíso 42:8-19.

Jancurová M, Minarovicov L, Dandar A (2009). Quinoa - A Review. Czech J Food Sci 27:71-79.

Jellen EN, Kolano BA, Sederberg MC, Bonifacio A, Maughan PJ (2011). Wild and weedy genetic resources for improving the quinoas (genus Chenopodium L.). In: Kole, C. (Ed). Wild Crop Relatives: Genetic and Breeding Resources 4:35-62.

Jorquera C (2001). Evolución Agropecuaria de la Región de Coquimbo: Análisis Contextual para la Conservación de la Vegetación Nativa. In: Squeo FA, Arancio G, Gutiérrez JR (eds.). Libro Rojo de la Flora de la Región de Coquimbo, y de los Sitios Prioritarios Para su Conservación, p. 386. Ediciones Universidad de La Serena, La Serena, Chile.

Junge I (1978). La Quinoa y Lupinus en Chile. Thesis, Universidad de Concepción, Chile.

Kadereit G, Borsch T, Welsing K, Freitag H (2003). Phylogeny of Amaranthaceae and Chenopodiaceae and the evolution of C4 photosynthesis. Int J Plant Sci 164:959-986.

Kolano B, Gardunia BW, Michalska M, Bonifacio A, Fairbanks D, Maughan PJ, Coleman CE, Stevens MR, Jellen EN, Maluszynska J (2011). Chromosomal localization of two novel repetitive sequences isolated from the Chenopodium quinoa Willd. genome. Genome 54:710-717.

Köppen W (1931). Grundiss der klimakunde. Gruiter Editions, Berlin.

Lanino I (1976). La Quínoa: Cultivo del altiplano chileno, zona de Isluga. Universidad del Norte, Sede Iquique, Chile.

Looser G (1943). Chenopodium quinoa, un cultivo que desaparece de Chile. Revista Argentina de Agronomía 10:111-113.

Lutz M, Martínez EA, Martínez A (2013). Daidzein and genistein contents in seeds of quinoa (Chenopodium quinoa Willd) from local ecotypes grown in arid Chile. Ind Crop Prod 49:117-121.

Mason SL, Stevens MR, Jellen EN, Bonifacio A, Fairbanks DJ, Coleman CE, McCarty RR, Rasmussen AG, Maughan PJ (2005). Development and use of microsatellite markers for germplasm characterization in quinoa (Chenopodium quinoa Willd.). Crop Sci 45:1618-1630.

Martínez EA, Delatorre J, San Martín R, Pinto M (2008). Asociación entre diversidad genética, calidad y cantidad de saponinas y respuesta al fotoperíodo en accesiones chilenas de Chenopodium quinoa Willd. FONDECYT Project. Final Report.

Martínez EA, Veas E, Jorquera C, San Martín R, Jara P (2009). Re-introduction of Chenopodium quinoa Willd. into arid Chile: Cultivation of two lowland races under extremely low irrigation. J Agron Crop Sci 195:1-10.

Martínez EA, Bazile D, Thomet M, Delatorre J, Salazar E, LeonLobos P, Von Baer I, Nuñez L (2010). Neo-liberalism in Chile and its impacts on agriculture and biodiversity conservation: the experience with the re-start of quinoa crop cultivation. Innovation and Sustainable Development, ISDA 2010. Montpellier, France. http://hal.archives-ouvertes.fr/ISDA2010.

Matiacevich SB, Castellión ML, Maldonado SB, Buera MP (2006). Water-dependent thermal transitions in quinoa embryos. Thermochim Acta 448:117-122.

Miranda M, Bazile D, Fuentes F, Vega-Gálvez A, Uribe E, Quispe I, Lemus R, Martínez EA (2011). Quinoa crop biodiversity in Chile: an ancient plant cultivated with sustainable agricultural practices and producing grains of outstanding and diverse nutritional values. In: 6th International CIGR Technical Symposium - Section 6: "Towards a Sustainable Food Chain" Food Process, Bioprocessing and Food Quality Management. Nantes, France.

Miranda M, Vega-Gálvez A, Quispe-Fuentes I, Rodríguez MJ, Maureira H, Martínez EA (2012a). Nutritional aspects of six quinoa (Chenopodium quinoa Willd.) ecotypes from three geographical areas of Chile. Chil J Agr Res 72: 175-181.

Miranda M, Vega-Gálvez A, Martinez EA, López J, Rodríguez MJ, Henríquez K, Fuentes F (2012b). Genetic diversity and comparison of physicochemical and nutritional characteristics of six quinoa (Chenopodium quinoa Willd.) genotypes cultivated in Chile. Food Science and Technology 32:835843.

Miranda M, Vega-Gálvez A, Martínez EA, Lopez J, Marin R, Aranda M, Fuentes F (2013). Influence of contrasting environments on seed composition of two quinoa genotypes: nutritional and functional properties. Chil J Agr Res 73:108116. 
Molina JI (1810). Ensayo sobre la historia Natural de Chile. Libro III Vegetales de Chile.

Orsini F, Accorsi M, Gianquinto G, Dinelli G, Antognoni F, Ruiz-Carrasco KB, Martínez EA, Alnayef M, Marotti I, Bosi $S$, Biondi $S$ (2011). Beyond the ionic and osmotic response to salinity in Chenopodium quinoa: functional elements of successful halophytism. Funct Plant Biol 38:818-831.

Parra F (2007). La cultura del territorio: la naturaleza contra el campo. Ciudad y Territorio, Estudios Territoriales 39:27-51.

Planella MT, Scherson R, McRostie V (2011). Sitio El Plomo y nuevos registros de cultígenos iniciales en cazadores del Arcaico IV en alto Maipo, Chile central. Chungara 43:189202.

Rana TS, Narzary D, Ohri D (2010). Genetic diversity and relationships among some wild and cultivated species of Chenopodium L. (Amaranthaceae) using RAPD and DAMD methods. Current Science 98:840-846.

Rescia A, Schimtz MF, De Pablo CTL, Pineda FD (2002). Organización, dinámica y diversidad del territorio, p 111-123. In: Pineda FD, De Miguel JM, Casado MA, Montalvo J (Eds.). La diversidad biológica de España. Vol IV, Prentice Hall, Madrid.

Rojas W (2003). Multivariate analysis of genetic diversity of Bolivian quinoa germplasm. Food Rev Int 19:9-23.

Ruas PM, Bonifacio A, Ruas CF, Fairbanks DJ, Andersen WR (1999). Genetic relationship among 19 accessions of six species of Chenopodium L., by Random Amplified Polymorphic DNA fragments (RAPD). Euphytica 105:25-32.

Ruiz-Carrasco KB, Antognoni F, Coulibaly AK, Lizardi S. Covarrubias A, Martínez EA, Molina-Montenegro MA, Biondi S, Zurita-Silva A (2011). Variation in salinity tolerance of four lowland genotypes of quinoa (Chenopodium quinoa Willd.) as assessed by growth, physiological traits, and sodium transporter gene expression. Plant Physiol Bioch 49:13331341.

Ruiz KB, Biondi S, Oses R, Acuña-Rodríguez IS, Antognoni, F, Martínez EA, Coulibaly AK, Pinto M, Canahua-Murillo A, Zurita-Silva A, Bazile D, Jacobsen SE, Molina-Montenegro MA (2014). Quinoa biodiversity and sustainability for food security under climate change. A review. Agron Sustain Dev 34:349-359.
Schlick G, Bubenheim DL (1996). Quinoa: Candidate crop for NASA's Controlled Ecological Life Support Systems, p 632640. In: Janick J (Ed.). Progress in New Crops, ASHS Press: Arlington, USA.

Simmonds NW (1965). The grain Chenopods of the tropical American highlands. Econ Bot 19:223-235.

Smith BD (2006). Eastern North America as an independent center of plant domestication. Proceedings of the National Academy of Sciences - PNAS 103:12223-12228.

Squeo FA, Arancio G, Gutiérrez JR (2001). Libro Rojo de la flora de la Región de Coquimbo, y de los sitios prioritarios para su conservación. Ediciones Universidad de La Serena, La Serena, Chile.

The Economist (2012). The Andes' new cash crop: Quinoa selection. Foreign interest grows in an old highland staple. http://www.economist.com/node/21554570/print.

Vega-Gálvez A, Miranda M, Vergara J, Uribe E, Puente L, Martínez EA (2010). Nutrition facts and functional potential of quinoa (Chenopodium quinoa Willd.), an ancient Andean grain: a review. Journal of the Science of Food and Agriculture 90:2541-2547.

Von Baer I, Bazile D, Martínez EA (2009). Cuarenta años de mejoramiento de la quínoa (Chenopodium quinoa Willd.) en la Araucanía: Origen de "La Regalona-B”. Revista Geográfica de Valparaíso 42:34-44.

Wilson HW, Heiser CB (1979). The origin and evolutionary relationships of 'huauzontle' (Chenopodium nuttaliae Safford), domesticated chenopod of Mexico. American Journal of Botany 66:198-206.

Wilson HD (1988a). Quinoa biosystematics I: domesticated populations. Econ Bot 42:461-477.

Wilson HD (1988b). Quinoa biosystematics II: free living populations. Econ Bot 42:478-494.

Wilson HD (1990). Quinua and relatives (Chenopodium sect. Chenopodium subsect. Cellulata). Econ Bot 64:92-110.

Wilson HD, Manhart J (1993). Crop/weed gene flow: Chenopodium quinoa Willd. and C. berlandieri Moq. Theor Appl Genet 86:642-648.

Zurita-Silva A, Fuentes F, Zamora P, Jacobsen SE, Schwember A (2014). Breeding quinoa (Chenopodium quinoa Willd.): potential and perspectives. Mol Breeding 34:13-30. 